Article

\title{
Trying to Smart-In-Up and Cleanup Our Act by Linking Regional Growth Planning, Brownfields Remediation, and Urban Infill in Southern Ontario Cities
}

\author{
Christopher De Sousa
}

School of Urban and Regional Planning, Ryerson University, Toronto, ON M5B 2K3, Canada; E-Mail: chris.desousa@ryerson.ca

Submitted: 8 May 2017 | Accepted: 17 July 2017| Published: 24 August 2017

\begin{abstract}
The reuse of brownfields as locations for urban intensification has become a core strategy in government sustainability efforts aimed at remediating pollution, curbing sprawl and prioritizing renewal, regeneration, and retrofitting. In Ontario, Canada's most populous, industrialized, and brownfield-laden province, a suite of progressive policies and programs have been introduced to not only facilitate the assessment and remediation of the brownfields supply, but to also steer development demand away from peripheral greenfields and towards urban brownfields in a manner that considers a wider regional perspective. This article examines the character and extent of brownfields infill development that has taken place in three Ontario cities (Toronto, Waterloo, and Kingston) since the provincial policy shift in the early 2000s. Using property assessment data and cleanup records, the research finds that redevelopment activity has been extensive in both scale and character, particularly in Toronto where the real estate market has been strong. While the results are promising in terms of government efforts to promote smarter growth that builds "in and up" instead of out, they also reveal that government could be doing more to facilitate redevelopment and influence its sustainability character, particularly in weaker markets.
\end{abstract}

\section{Keywords}

brownfields; contamination; development; infill; smart growth; sustainability

Issue

This article is part of the issue "Smart Solutions for Sustainable Cities", edited by Tom Sanchez (Virginia Tech, USA), Ralph Hall (Virginia Tech, USA) and Nader Afzalan (Redlands University, USA).

(C) 2017 by the author; licensee Cogitatio (Lisbon, Portugal). This article is licensed under a Creative Commons Attribution 4.0 International License (CC BY).

\section{Introduction}

The redevelopment of brownfields has become a core strategy in government efforts aimed at cleaning up past pollution while working towards a more sustainable future. While the initial attention of policy-makers in the 1980s focused narrowly on understanding, assessing, and remediating the risks posed by contamination, the focus began to broaden in the 1990s to redeveloping brownfields in an effort to bring people, jobs, and taxes back to communities afflicted by deindustrialization. As the new millennium has unfolded, policy makers have expanded the socio-economic and environmental benefits that they hope can be gleaned from reusing brownfields, ranging from sustainable remediation and building, to the provision of affordable housing and combatting cli- mate change. Yet the core objective of brownfields redevelopment from a sustainability perspective continues to lie in the strategic reuse of these properties as locations for urban intensification to combat urban sprawl (Dixon, 2007; Kirkwood, 2001).

In Ontario, Canada's most populous, industrialized, and brownfield-laden province, a suite of progressive government policies and programs have been introduced to not only facilitate the assessment and remediation of the brownfields supply by the development industry, but to also steer development demand away from peripheral greenfields and towards brownfields through integrated planning and policy that considers a wider regional perspective. In 2004, Ontario's Ministry of the Environment and Climate Change (MOECC) amended the Environmental Protection Act (MOECC, 1977) to estab- 
lish a voluntary cleanup regime wherein private landowners, developers, and their environmental consultants were largely responsible for assessing and remediating brownfields to government standards with minimal bureaucratic intervention. The provincial Ministry of Municipal Affairs and Housing (MMAH) also granted municipalities additional land-use and tax tools to facilitate brownfield redevelopment within designated Community Improvement Plan (CIP) areas through the Planning and Conservation Land Statute Law Amendment Act (MMAH, 2006a, 2007) and the Brownfields Financial Tax Incentive Program (MMAH, 2008). In an effort to drive demand towards brownfields and other infill opportunities, the Places to Grow Act (MMAH, 2005a) was passed to allow the government of Ontario to prepare plans for population growth and economic expansion within existing urban zones, while protecting the environment, agricultural lands, and other resources in the periphery. Most attention focused on the fast-growing Greater Golden Horseshoe located along the North and West shore of Lake Ontario, which includes the city of Toronto and other municipalities that account for nine of the province's thirteen and a half million residents.

This paper examines the nature of property development that has taken place on brownfields in a handful of Ontario cities (i.e., Toronto, Waterloo, and Kingston) since the provincial policy shift towards using these sites to deliver smarter growth. Using property assessment data and so-called Records of Site Condition (RSC) submitted by those who assess and remediate brownfields, the present examination investigates the scale, character, and value of redevelopment activity in detail. Although it is not possible to determine the direct extent to which remediation policy, growth management policy, and/or pure market forces contributed to the character of redevelopment activity during this period, the goal of the present study is to trace the type of brownfields redevelopment taking place in municipalities where these smart growth and remediation policies and forces are working together in a coordinated fashion. In North America, where brownfields remediation and redevelopment policies and approaches have been largely voluntary and the issue has been tackled on a site-by-site basis, Ontario provides an example of where upper levels of government have sought to take an approach more akin to the UK and Europe where sustainable development and brownfield policy agendas are more interlinked.

\section{Cleaning up Our Act: Brownfields Remediation and Redevelopment Policy in Ontario}

The MOECC (2015) defines brownfields as "vacant or underutilized places where past industrial or commercial activities may have left contamination (chemical pollution) behind." Formal regulatory efforts aimed at protecting land resources started with the enactment of the Environmental Protection Act (MOECC, 1971), which prohibited the discharge of a contaminant into the environ- ment that may cause adverse effects. The emergence of regulatory challenges associated with brownfields, together with scientific improvement in testing, lead to the MOECC's Guidelines for the Decommissioning and Cleanup of Sites in Ontario (1989) and Interim Guideline for the Assessment and Management of Petroleum Contaminated Sites (1993), both of which continued to evolve thereafter as pollution standards for new contaminants were added or modified.

Even though the Ontario government maintains the right to order the cleanup of a property, the MOECC began to favor a voluntary approach wherein a landowner was only required to remediate their property when they opted to. In general, someone interested in acquiring, remediating, and/or redeveloping a brownfield in Ontario typically embarks on the following. First, to ascertain the possibility of pollution risks, a qualified person (QP) conducts a Phase I Environmental Site Assessment (ESA) that usually includes a review of historical records to identify past risks and may also include a site visit and interviews with past/present owners/occupants. If concerns are identified, tests are then performed at the site as part of a Phase II ESA to determine the location, type, and degree of contamination. In Ontario, the Phase II ESA also includes, if necessary, a report describing the cleanup approach taken along with confirmation that the site meets applicable provincial standards (often referred to as a Phase III ESA in other jurisdictions).

Cleanup standards used in Ontario to assess whether a site is contaminated and to guide cleanup can be based on: (1) background (pristine nature) levels, which are somewhat unrealistic for urban environments; (2) generic levels wherein soil standards are based on (eco)toxicological exposure risks considered safe for different forms of land use (residential and park standards are higher than industrial, retail, and commercial ones); or (3) Site-Specific, Risk-Based, levels where standards are based on the tolerance and risk exposure associated with a particular project to be developed at a particular location. In the 1990s, the MOECC found itself increasingly involved in the review of site remediation plans and after a lengthy process of back and forth consultation the property owner ideally received a "letter of concurrence" from the Ministry to assure them that the site had passed standards and that no future remedial work would be necessary (Fishlock, 2011).

To facilitate remediation, the province began amending its brownfield policy in 2001 (MOECC, 2001) with the Ontario Regulation 153/04 (Record of Site Condition Regulation) officially coming into force on October 1 , 2004 (MOECC, 2004a, making further revisions in 2007, 2009 and 2011). The overarching goals were to establish clearer requirements for site assessments, provide some protection from environmental liability, and improve environmental site condition standards. The amendments enhanced and formalized the so-called Record of Site Condition (RSC), which is a report submitted by a property owner outlining the environmental condition of a 
property at a particular point in time based on ESAs and also contains information related to property ownership, location, and other supporting documents. The amendments also obliged property owners to file a RSC when land use changed (from industrial/commercial to residential/parkland) and outlined the requirements for the QP responsible for completing ESAs and for submitting RSCs to the Ministry. Only in the case of a risk-based cleanup is the QP required to provide information from Phase I and II ESA results and a public communications plan to the Ministry for approval prior to conducting and submitting a RSC. Otherwise, completed RSCs are submitted by the QP to the province, where they are checked for administrative and technical errors and then filed on the Environmental Site Registry.

During the same period, Ontario's Ministry of Municipal Affairs and Housing led provincial efforts to support brownfield redevelopment through policy and technical assistance. In 2005, the Ministry established the Office of the Brownfields Coordinator to facilitate its work and to support municipalities. Government amendments to the Planning Act (MMAH, 2006b) allowed municipalities to create Community Improvement Plans (CIP) in order to help developers manage brownfields in CIP areas by offering them financial incentives (e.g., Feasibility Study Grants to support ESAs, Remediation Grants to support cleanup activities, Municipal Fee Grants to reimburse application fees, Tax Increment Grants to help property owners undertake projects, etc.). Research undertaken by MMAH (2010, p. 5) revealed that 44 Ontario municipalities had adopted CIPs containing brownfield provisions. According to that study, the City of Kingston was an early adopter, with its CIP approved in 2006 for part of its municipality and offering incentive programs related to tax assistance, tax increment equivalent grants, study grants, and grants for miscellaneous fees. The City of Toronto's CIP approved in 2008 covers the entire municipality and allowed for tax assistance, tax increment equivalent grants, and development charges reductions/exemptions, but only for employment uses. The City of Waterloo just introduced its CIP in 2013, however the regional municipality of Waterloo has had one since 2005 that allowed it to offer various incentives within the plan area.

\section{Smartening Up: Growth Management Policy}

Passed in 2005, the Places to Grow Act responded to decades of concern from urban stakeholders regarding the costs and negative consequences of urban sprawl and marked the government's overarching commitment to sustainability and smart growth. The first growth plan under this legislation was the Growth Plan for the Greater Golden Horseshoe (Ministry of Infrastructure, 2013) that focuses urban and suburban growth into already built up areas, while the Greenbelt Plan (MMAH, $2005 \mathrm{~b}$ ) protects agricultural greenfields and ecological systems that frame the region. The Growth Plan (Min- istry of Infrastructure, 2013, p. 12) explicitly states that it "envisages increasing intensification of the existing builtup area, with a focus on urban growth centres, intensification corridors, major transit station areas, brownfield sites and greyfields."

The Growth Plan builds on a long history of regional planning in Toronto that dates back to the late 1940s. According to White (2007, p. 5), however,

the ambitions of the new Growth Plan are historically unprecedented" because it "proposes not just to plan the region, but to change it: to re-direct development from the urban-edge into existing urban areas, to encourage new suburbs to be built as 'complete' live/work communities [not just 'bedroom' communities] and to establish a multiplicity of new corridors that do not exist yet.

White notes that while the province's regional planning program in the 1950s and 1960 s succeeded in realizing its physical planning objectives for metropolitan Toronto, the lofty regional planning goals put forward in the late 1960 s and early 1970s failed to materialize as municipal autonomy gained strength. Regional growth planning efforts were resurrected again in the early 2000s as growth pressure from Toronto (2.5 million) and the surrounding suburb (2.5 million) pushed into the environmentallysensitive Oak Ridges Moraine North of Toronto and the Conservative provincial government of the time, despite being anti-interventionist, embraced populist support for smart growth planning. The stage was therefore set for the newly elected Liberal government in 2004 to quickly embark on what White $(2007$, p. 44$)$ refers to, as "an ambitious program of regional planning."

The other cities examined in the present study also have strong regional growth planning traditions. Officially established in 1973, the Waterloo Region has a population of over half a million residing in the cities of Cambridge, Kitchener, and Waterloo as well as various townships. The Regional Municipality of Waterloo embarked on the development of a growth strategy in 2001 focused on sustainability and liveability, which led to the formal adoption of the Regional Growth Management Strategy in 2003 that seeks to accommodate the majority of new growth in existing urban areas. The region also prepared a Guideline for the Review of Development Applications Involving Known and Potentially Contaminated Sites (Region of Waterloo, 2009) to balance intensification targets and the promotion of brownfield redevelopment with the protection of municipal water supplies and public health by outlining procedures to align remediation with the planning review process. The city of Kingston embarked on an urban growth strategy study in 2002 soon after undergoing an amalgamation in 1998. The strategy included considerations such as the urban boundary, phasing, commercial development, smart growth, density, infilling, alternative development standards, greenhouse reduction commitments and related issues (City 
of Kingston, 2004). The study found that the projected growth rate could largely be accommodated in the existing community development area in the core of Kingston via increased residential density and mixed land use. The strategy was approved in 2006 and results formally incorporated with requirements of the provincial Growth Plan via the municipal Official Plan.

\section{Literature Review}

International research that includes Canada has argued that there is an ongoing convergence in policy-making both within Canada and within the US and Western Europe as governments become more cognizant of the types of costs and risks they must share with the private development sector to solve the problem effectively (Adams, De Sousa, \& Tiesdell, 2010). Kirkwood's (2001) conceptual framework, based largely on the US experience, explains how the theory and practice of brownfield redevelopment has evolved and converged in three phases. The first phase experienced a theoretical and practical focus on the science of environmental cleanup spurred by pollution disasters such as Love Canal. This was followed by a second phase beginning in the late 1980s, with a theoretical focus on economic development and a practical focus on redevelopment aimed at building up the economic base of communities that ultimately led to new federal policy efforts in the 1990s. In the third and most recent phase, Kirkwood (2001, p. 5) claims that the practice of brownfield redevelopment in the US has yet to catch up with the theory that has become situated in integrated planning models that stress wider regional concerns.

The evolution of brownfields regeneration policy in Europe and the UK is much further along in terms of aligning brownfields redevelopment with wider regional concerns and, more specifically, the sustainable development policy agenda. Dixon (2007, p. 2381) notes that since 1997 the UK government has used brownfield recycling to underpin urban regeneration and firmly linked it with sustainability. This has been enshrined in English national policy and underwritten in planning policy guidance in which brownfield housing targets by the late 1990s required half of all new homes to be built on reused sites (raised to $60 \%$ by 2008). Indeed, research has found that the relative proportion of new homes built on brownfields rose from $56 \%$ in 1997 to $64 \%$ by 2003 , and more aggressive efforts to assemble brownfield land and strengthen housing markets in city centers have made brownfields redevelopment increasingly lucrative since, reaching 123,000 units by 2005 (Adams, 2011, p. 953). More recent research by Sinnett, Carmichael, Williams and Miner (2014) found that regional governments have identified capacity for at least one million new homes on brownfields, with sites having existing planning permission able to accommodate more than 405,000 homes and a further 550,000 on other suitable vacant or derelict sites, including at least 146,000 in London.
Dixon (2007) develops a conceptual framework for understanding the evolving policy agenda associated with brownfield regeneration and the role of the private development industry. He first describes the popular POST model wherein the process of redeveloping brownfields encompasses: a 'policy push' aimed at getting redevelopment to achieve key sustainability benefits (i.e., urban regeneration, environmental improvement, greenfield protection); 'development frictions' caused by the costs, risks, and regulatory obstacles affecting remediation and redevelopment; and an 'opportunity pull' seeking the realization of benefits to all stakeholders in creating sustainable urban communities (i.e., developer profit, attractive locales for residents and employees). He then expands this conceptual framework by integrating it with the triple bottom line concept of sustainability in an effort to better understand how developers engage with sustainability at the local level to achieve a broader array of economic, social, and environmental goals. In a review of several development cases, he found that while developers seem to be adapting to POST's brownfield dynamic, they are struggling to come to terms with sustainability in all spheres and despite some success, there is continued skepticism over the sustainability agenda and the ability to approach it in an integrated way via brownfield regeneration projects.

North American researchers have also devoted growing attention to the relationship between brownfields, smart growth, and sustainability, albeit to a lesser degree than the Europeans and largely focusing on the site/project scale. Early reports by the US Environmental Protection Agency $(1998,1999)$ were some of the first to argue that communities needed to make significant advances toward sustainability by reusing brownfields. Several books by Greenstein and Sungu-Eryilmaz (2004), De Sousa (2008), Sarni (2009), and Hollander, Kirkwood and Gold (2010) review the issue of brownfields and sustainability and provide many examples and best practices, but are light on the role of policy to advance the issue at broader geographic scales. Numerous studies assess the contribution of brownfield projects to sustainability by examining individual indicators, such as the highly-cited work by Deason, Sherk and Carroll (2001) that found that 1 acre ( 0.405 ha) of brownfield land could accommodate the same development as 4.5 greenfield acres (1.8 ha). Others propose and/or employ a broader array of sustainability indicators to track redevelopment outcomes (De Sousa, 2002a; Nagengast, Hendrickson, \& Lange, 2011; Wedding \& Crawford-Brown, 2007). The work by Leigh and Hoelzel (2012) however, finds smart growth pursuits to be somewhat problematic in that they encourage the conversion of industrial brownfields to other uses, which weakens the urban economic base, reduces the supply of employment land, and contributes to industrial-sector suburban sprawl.

Scholarly research on brownfield redevelopment activity in Canada is both limited and dated. Research quantifying redevelopment activity in Toronto in the 1990s 
found that it was robust despite limited government intervention because of that city's strong residential and commercial real estate market and the willingness of the municipal government to plan for and support urban revitalization efforts through rezoning employment land and increasing density (De Sousa, 2002b). Work by Hayek, Arku and Gilliland (2010, p. 389) examining redevelopment efforts in London, Ontario (pop. 360,000), found through qualitative interviews that "despite the availability of financial incentives, the overall private sector participation in brownfield redevelopment is low due to barriers such as competition from greenfields [clean sites], risk, cost, negative public perception of brownfields, and complex remediation processes." The researchers also noted (2010, p. 392) that limited brownfield redevelopment activity was taking place in the city despite proactive municipal policy, with only 12 properties being subject of remediation since 2006 with most properties converted to high-density residential units and office spaces.

A recent paper by De Sousa (2015) found that privatesector brownfield stakeholders in southern Ontario continue to be motivated largely by real estate fundamentals (profit, market, location) and many felt brownfields redevelopment had become a standard transaction that is viable if the market permits. Interestingly, several developers also noted that public policy was driving them to brownfields because acquiring greenfields was becoming increasingly complicated. Other major obstacles included non-institutional barriers related to cost, liability, time, weak market demand, contamination, and a lack of available funding, while institutional barriers presented themselves at the provincial (e.g., duration/complexity of regulatory process and risk assessment) and municipal levels (e.g, limited municipal expertise on brownfields, complex development approvals). To maintain interest in strong markets and stoke it in weaker ones, interviewees called for more intervention from governments both indirectly, through the improvement of existing regulatory processes and tools, and directly, through greater funding and technical support.

While a greater number of scholarly studies have examined the nature of brownfield remediation and redevelopment activity in United States through their voluntary cleanup programs (e.g., Alberini \& Sigerson, 2002; Blackman, Darley, Lyon, \& Wernstedt, 2010; Guignet \& Alberini, 2010; Wernstedt, Blackman, Lyon, \& Novak, 2013), municipal surveys conducted by the US Conference of Mayors every few years since 1993 provide perhaps the best known snapshot of the scale and extent of redevelopment in that country. In the most recent survey (United States Conference of Mayors, 2010), 116 cities noted the redevelopment of 2,667 sites for a total of 11,096 acres into the following: 20,856 retail projects or individual retail units; 25,004 housing development projects or individual housing units; 1,328 mixed use projects; 260 commercial projects; 120 industrial projects; 223 parkland projects or acreage, and 63 other projects (e.g., educational facilities, government build- ings, etc.). Their report (US Conference of Mayors, 2010) examining activity from 1993 to 2010 also summarizes information on the number and acreage of brownfields redeveloped in numerous small to large cities located near southern Ontario, including Akron, Ohio (12 sites/24 hectares), Allentown, Pennsylvania (10/25), Binghamton, New York (2/14), Bridgeport, Connecticut (50/6), Cincinnati, Ohio (5/12.5), Columbus, Ohio (19/81), Indianapolis, Indiana (44/81), Kalamazoo, Michigan (30/42), Milwaukee, Wisconsin (90/81).

\section{Methods}

Data for the present study was gathered from several sources. First, information on the location of assessed and remediated brownfields was obtained from RSCs filed by property owners to Ontario's Environmental Site Registry between October 1, 2004 and June 30, 2011 (MOECC, 2004b). This time period was chosen for two reasons: (1) it considers projects conducted from the beginning of Ontario's new cleanup legislation in 2004 to where legislation was amended in 2011; and (2) given that the most recent property assessment data available for analysis was for the 2013 tax year, it allowed some time for projects to be built out. Each RSC report contains an array of information about the property, although the present study utilized it solely for data about location and ownership. For the city of Toronto, a total of 1000 RSCs were used from this period, with 415 collected and transcribed manually from online reports and 585 entries provided in a database by the MOECC. RSCs for Waterloo and Kingston were collected and transcribed manually from online reports. The city of Toronto was selected for examination because of its industrial legacy, large population size, strong property market, political status as the provincial capital, and, most importantly, its central focus in Ontario's growth plan. The city of Waterloo is a small city with a brownfields legacy that is part of the GTHA growth plan, but lies on its outer edge over 100 kilometers from Toronto. Kingston was selected because it is an older smaller city well outside of Toronto $(265 \mathrm{~km}$ and $290 \mathrm{~km}$ from Montreal) with experience in both brownfields redevelopment and growth management.

The second phase of data collection involved the retrieval of information about assessed value (land and buildings), building area, and tax class of property for Tax Year 2013 (based on assessments conducted in 2012). For Waterloo and Kingston, 2013 tax assessment information was purchased from the Municipal Property Assessment Corporation. For Toronto, more detailed property assessment information was collected manually by student researchers from the Municipal Property Assessment Corporation (MPAC) City of Toronto public terminals from September 2014 to June 2015. In addition, Toronto property data maps, urban planning staff reports, market reports and development real estate websites were used to determine the number of floors and units in residential buildings. Out of a total 1000 RSCs in 
Toronto from 2004 to 2011, five RSCs were removed from the analysis because the property addresses could not be found and/or the spatial coordinates were incorrect. Access to additional information from Toronto made it possible to perform a more in-depth market analysis of residential redevelopment, which was found to be particularly prevalent during the study period. The residential types were coded as single family detached, semidetached, row/townhouses, apartments, condominiums and mixed. Mixed classification included a combination of the aforementioned residential types, but the number of units could not be isolated through online resources. Therefore, 16 RSCs with the residential classification of Mixed were removed creating a total of 452 RSCs that were used to estimate number of units, square feet/acres and property value. Based on market reports from CBRE Canada, Canadian Home Builders Association (CBHA), Toronto Real Estate Board (TREB), the Globe and Mail, the Toronto Star and online real estate blogs, the average price and size of a residential dwelling was estimated to get an average price per square foot. The average price per square foot was multiplied by the total number of residential units to determine the building area and property value created by dwelling type. Data on average persons per household by dwelling type from the 2011 Census of Population and Statistics Canada (by Census Metropolitan Area) was used to estimate the number of people accommodated in residential units for each of the cities examined. It should be noted that this estimate is limited however, because the size of the sample is inferred from group data, which includes older and larger housing stock. For the City of Toronto (2015), a planning report based on Statistics Canada's National Housing Survey was also used to estimate the population in residential units because it contains 2011 data on average persons per household by dwelling type for newer housing stock (built from 2006-2011), which is more accurate and comparable to the projects examined in the present study.

It was also possible to have research assistants gather information to conduct a pre-post analysis for the city of Toronto. This fourth phase of data collection compared the assessment value of Tax Year 2013 with the Tax Year 2003, which was manually collected at the Toronto Archives from September 2014 to July 2015. Given the large magnitude of data collection for this study, gathering 400 RSCs for both Tax Years 2003 and 2013 was considered to be a significant sample size at $\alpha=0.01$ with a $5 \%$ margin of error and $99 \%$ confidence interval. Using the DigDB roll up function in Excel, 409 RSCs were matched between the two tax years. The 2003 tax year values were adjusted using an average annual inflation rate of $1.79 \%$ over a 10 year period according to the Bank of Canada.

Several challenges and limitations affected the ability to gather data for the present study. First, the cost of obtaining property assessment data from the Municipal Property Assessment Corporation is prohibitive for an academic institution using this data for research purposes. The procedure to collect older data was difficult and while researchers were able to access the Toronto archives, this was not an option for the other municipalities. In terms of GIS data, partnering with municipalities was often laborious and while most municipalities have free online GIS data, the information available and file versions were sometimes limited and dated. Furthermore, the absence of accessible public information regarding the use of public incentives to support individual brownfield projects made it impossible assess their application.

\section{Results}

\subsection{Toronto}

A total of 1000 Records of Site Condition were filed in the City of Toronto from 2004-2011. The RSCs (979) with data on site area addressed 926.7 ha $(2,290 \mathrm{ac})$ of land, with an average per RSC of 0.9 ha $(2.3 \mathrm{ac})$ and a median of 0.2 ha $(0.5 \mathrm{ac})$. While most RSCs (69.1\%) applied to the entire property, $30.9 \%$ of them were only filed for a portion of it. As expected, most RSCs were filed for brownfields that were commercial (46.9\%) and industrial (25.0\%) properties, although many were also filed for residential (16.9\%), institutional (2.8\%), community $(2.8 \%)$, agricultural/other $(2.1 \%)$, and parkland $(1.4 \%)$ uses $(2 \%$ n.a.). The most common "intended" use identified in the RSCs was residential $(66.2 \%)$, followed by commercial $(12.1 \%)$, community $(6.8 \%)$, parkland $(4.8 \%)$, industrial (4.3\%), institutional (3.7\%), and agricultural/other (0.1\%) (2\% n.a.).

As for site assessment and cleanup, 16.3\% of properties only filed a Phase 1 ESA. Most filed a Phase 1 and 2 ESA (77.1\%) involving generic standards and only a small share $(6.6 \%)$ employed risk-based procedures. Interestingly, most brownfield properties intended for residential use either required a Phase 1 ESA (14.7\%) or applied a Phase 1 and 2 ESA (83.2\%) utilizing the more conservative generic standards, with very few opting for a riskbased approach (2.4\%). It should also be noted that while only a few dozen RSCs outlined a specific cleanup approach, the vast majority of projects involved the excavation and removal of soils (63\% of Phase 1 and 2 ESAs and $55 \%$ of RA sites) and/or deposited soil (30\% of Phase 1 and 2 ESA and $48 \%$ of RA sites) pointing to the high application of so-called dig-and-dump as in the UK.

Merging the RSC dataset and the property assessment records for Toronto required the elimination of the five records that lacked spatial coordinates, while another thirty-five were retained but could not be used to the full extent because the building was not yet built or had no tax information. These 995 projects reused 1,161 hectares $(2,868 \mathrm{ac})$ of property. Slightly under half of this took place in downtown core of the old City of Toronto (47\%, $546 \mathrm{ha} / 1,349 \mathrm{ac})$ and the remainder in the surrounding inner suburbs that were amalgamated with the 
old City of Toronto in 1998 (257 ha/636 ac in Scarborough, 180 ha/447 ac North York, 126 ha/312 ac Etobicoke, $33 \mathrm{ha} / 81$ ac East York, $17 \mathrm{ha} / 43$ ac in York) (See Figure 1). A total of 86,843 units were redeveloped on these properties with most in central Toronto $(55,220)$ and North York $(15,423)$ followed by the lower density inner suburbs (Etobicoke 7,210, Scarborough 7,041, East York 1,142, York 807). The lion's share of these units are residential $(83,020$; or 84,187 if residential units in "mixed" developments are included) with most in the central Toronto $(53,286)$ followed by North York $(15,319)$, Etobicoke $(6,945)$, Scarborough $(5,585)$, East York $(1,113)$ and York (772). Interestingly, the City of Toronto (2016, p. 3) recently reported that 14,338 dwellings were completed per year on average from 2006-2015, which one could use to infer that dwellings on brownfields represented about $70 \%$ of this total.

Using 738 records from which building story information could be gleaned, it is possible to visualize the density of brownfields development, which has been largely residential with some offices (commercial). As Figure 2 illustrates, density has concentrated in the downtown core within Toronto's provincially designated Downtown Urban Growth Centre, as well as along the city's historic North/South arterial route (Yonge Street and subway that lies beneath it) that traverses the provincially designated growth centers of Downtown Centre, Yonge-Eglinton, and North York. Dense growth has also taken place along the main highways and along the major East/West transit corridors (Bloor subway/St. Clair streetcar).

As mentioned, a more in-depth analysis of residential brownfields redevelopment was conducted in Toronto due to data accessibility. 452 RSCs were used to estimate the number of units, property area, unit area, and property value. In total, 84,187 residential units were constructed with $84.5 \%$ in condominium apartments, $8.1 \%$ in row/townhouses, $4.9 \%$ rental apartments, $0.9 \%$ single family homes, $0.3 \%$ semi-detached homes, and $1.4 \%$ in mixed unit developments. Given the difficulty of isolating housing units in mixed-unit developments $(1,167$ units), those 16 RSCs were removed from further analysis leaving 83,020 units. Overall, condominium apartments represented most of the redevelopment with 71,079 units on 529 ha $(1,307 \mathrm{ac})$ of reclaimed land. Using average size and price data, it can be estimated that condominiums added 5,289,369 $\mathrm{m}^{2}\left(56,934,297 \mathrm{ft}^{2}\right)$ of living space and $\$ 28 \mathrm{~B}$ in property value to the Toronto market. The 4,109 rental apartments reclaimed 31 hectares (76 ac) of land and accounted for 305,772 $\mathrm{m}^{2}$ $\left(3,291,309 \mathrm{ft}^{2}\right)$ and $\$ 763,168,165$ in market value. In terms of ground-related housing, row/townhouses were increasingly popular during this period with 6,820 units constructed on 219 acres ( 89 ha) of reclaimed land and adding an estimated $887,038 \mathrm{~m}^{2}\left(9,548,000 \mathrm{ft}^{2}\right)$ of living space and $\$ 3,656,965,840$ in value to the market. The smallest share of units were single family (772) and semi-detached (240) houses, which accounted for less area (14ha/35ac and $3 \mathrm{ha} / 7 \mathrm{ac})$ and square feet $\left(143442 \mathrm{~m}^{2} / 1,544,000 \mathrm{ft}^{2}\right.$ and 29,208 $\left.\mathrm{m}^{2} / 314,400 \mathrm{ft}^{2}\right)$, but added significant market value $(\$ 769,506,440$ and $\$ 171,878,400)$. In all, it can be estimated that 148,551 to 222,152 people have been accommodated in the 83,020 housing units on reclaimed brownfields during the study period. As mentioned, the low estimate is based on a Toronto planning report containing 2011 average persons per household by dwelling type for newer housing stock (built in 2006-2011), which takes into consideration the smaller physical size of newer units (the population would be 176,937 if dwelling age is not considered), while the high estimate is based on Statistics Canada persons per household approximations in 2011 for the Toronto CMA (range by dwelling type $=119,413$

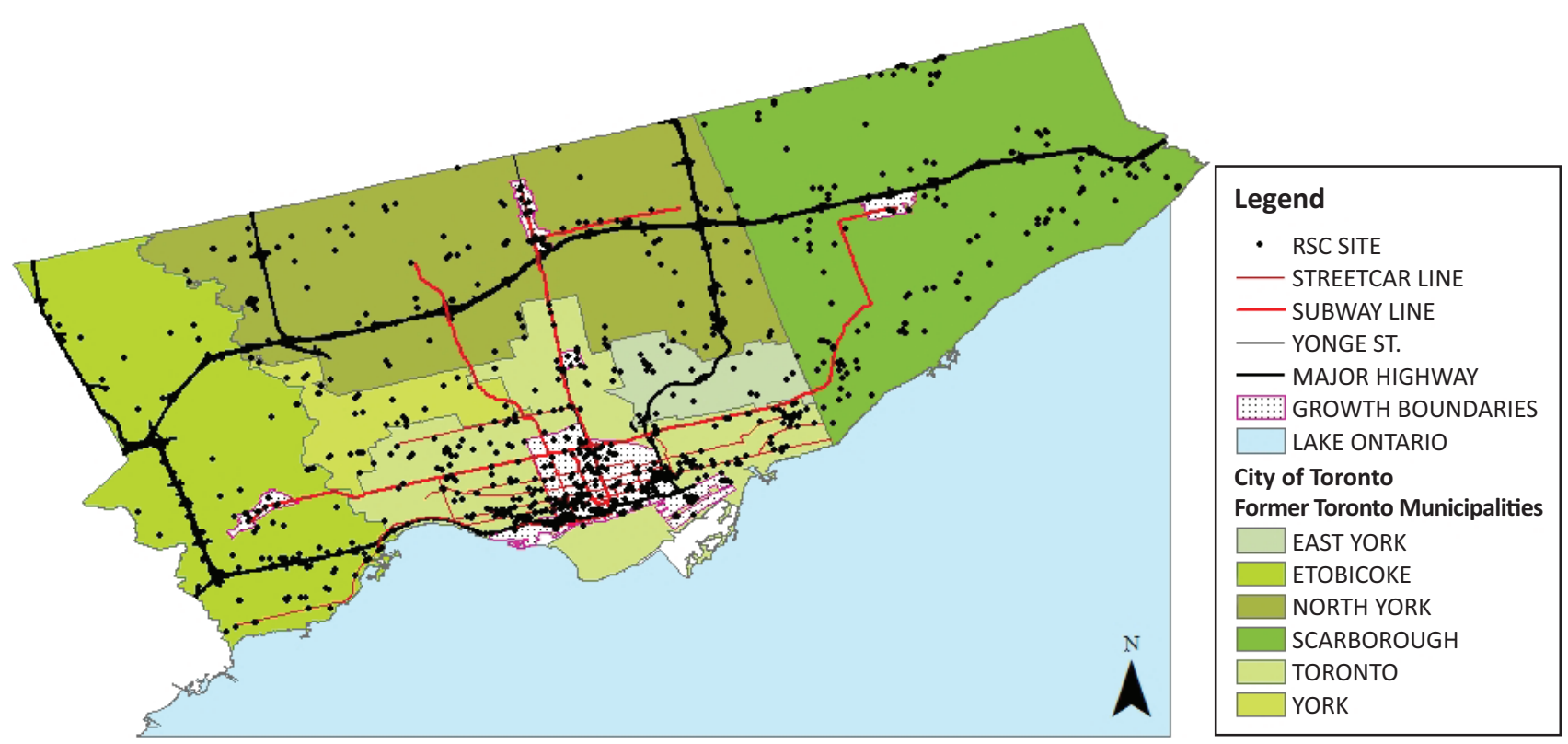

Figure 1. City of Toronto (995 RSCs 2004-2011). 

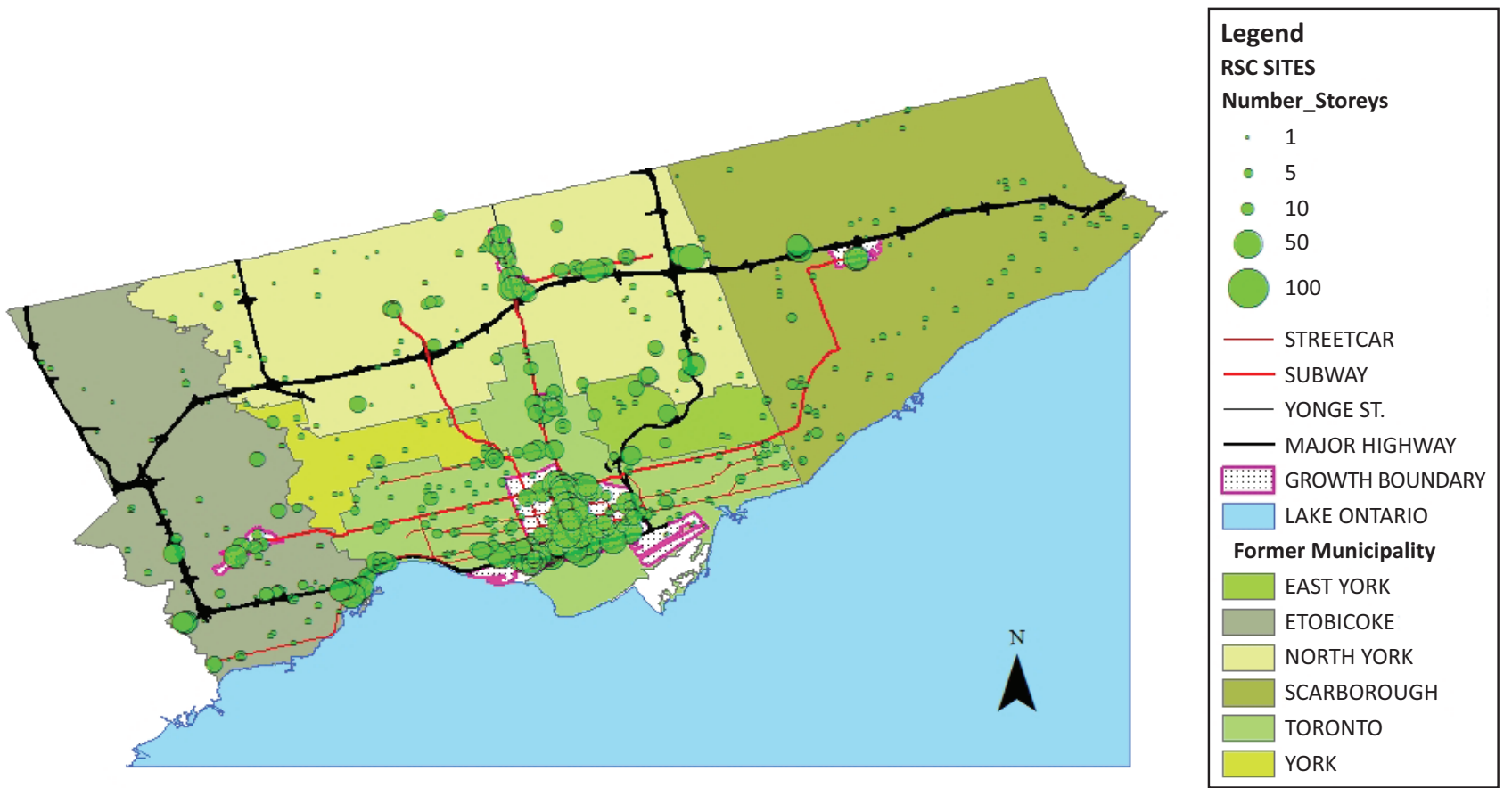

Figure 2. Building density and storeys, City of Toronto (738 RSCs 2004-2011).

to 191,913 in condominiums, 6,903 to 8,629 in rental apartments, 19,301 to 18,414 in row/townhouses, 2,239 to 2,548 in single family dwellings, and 696 to 648 in semidetached dwellings; based on 452 RSCs).

Overall, the total assessed property value for all brownfield properties in the 2013 tax year was $\$ 37.1$ billion dollars, with the greatest value in central Toronto (\$22.7 billion) followed by North York $(\$ 6.6 \mathrm{~B})$, Scarborough $(\$ 4.7 \mathrm{~B})$, Etobicoke $(\$ 2.7 \mathrm{~B})$, York $(\$ 0.3 \mathrm{~B})$, and East York (\$0.2B). Access to archived tax information made it possible to estimate the value of a sample of these developments in relation to what they would have been worth had site assessment, cleanup and redevelopment not occurred (409 RSCs were matched between Tax Years 2003 and 2013). Adjusting 2003 information to "current values" (using an average annual inflation rate of $1.79 \%$ ) and comparing it to actual 2013 tax values revealed that assessed value increased most in Toronto's downtown core $(\$ 9.8 \mathrm{~B})$ over the 10 -year period, particularly along the waterfront, followed by the inner suburbs (North York \$2.2B, Scarborough \$1.4B, Etobicoke $\$ 1.2 B$, York \$0.2B, East York \$0.1B). In terms of percentage change, relative property tax value between 2003 and 2013 increased significantly in all locations (central Toronto 1,314\%, Scarborough 1,026\%, York 877\%, East York 706\%, North York 631\%, and Etobicoke 499\%). Interestingly, while the bulk of the assessment value was unlocked in the downtown waterfront, the highest percent change in property values occurred in older warehouse industrial and low-density residential communities near the downtown as density and demand spread into those areas. As for the residential subset of projects (452 RSCs), the average price per dwelling was estimated at $\$ 394,504$ for a condo $\left(801 \mathrm{ft}^{2} / 74 \mathrm{~m}^{2}\right), \$ 536,212$ for a row/town house $\left(1,400 \mathrm{ft}^{2} / 130 \mathrm{~m}^{2}\right), \$ 715,160$ for a semidetached $\left(1,310 \mathrm{ft}^{2} / 122 \mathrm{~m}^{2}\right)$, and $\$ 996,770$ for a singlefamily dwelling $\left(2000 \mathrm{ft}^{2} / 186 \mathrm{~m}^{2}\right)$. Although data were not gathered in a manner that allows for an analysis of residential affordability, the City of Toronto $(2015$, p. 19) did find that affordability for homeowners remained fairly stable between 1995 and 2010 because price increases were balanced by income growth and lower interest rates, while rental housing affordability improved slightly as the rent-to-income ratio fell. That said, the report (p. 19) also notes Toronto's housing affordability problems are "growing due to income disparity, limited rental supply, low vacancy rates, single income households, and tight market conditions." It should also be mentioned that while only a small share of RSCs directly affected residential sites (16.9\%) and may have caused displacement, the large-scale conversion of commercial, industrial, and other uses to satisfy the higher demand for residential development does raise concerns regarding declining affordability, lost employment opportunity, and gentrification in surrounding areas.

\subsection{Waterloo}

Twenty-four RSCs were filed in the City of Waterloo from 2004 to 2011 with 18 of those applying to the entire property (see Figure 3 ). The total land area reclaimed was 15.5 hectares $(38.3 \mathrm{ac})$ with an average per record of 0.65 ha $(1.59 \mathrm{ac})$ and a median of 0.28 ha $(0.69 \mathrm{ac})$. Over half of the sites (13 or 54\%) were previously commercial followed by industrial ( 5 or $20.8 \%$ ), residential (3 or $12.5 \%$ ), and one each for community, parkland, and agricultural. Most of the brownfields were intended for residential (17 or $70.8 \%$ ) and commercial (4 or $16.7 \%$ ) 
use according to the RSCs, followed by industrial ( 2 or $8.3 \%$ ) and community ( 1 or $4.2 \%$ ). In terms of site assessment and cleanup, a large share only filed a Phase 1 ESA (5 or $20.8 \%$ ), while most undertook a Phase 1 and 2 ESA (75\%) and only 1 project employed risk assessment. Only a quarter of the projects noted the removal or deposit of soil.

The 24 RSCs generated 29 assessed properties for the tax year 2013 ( 5 being mixed use) and resulted in the redevelopment of 58 hectares (143 ac) with an average of $2.3 \mathrm{ha}(5.7 \mathrm{ac})$ and a median of $0.8 \mathrm{ha}(2 \mathrm{ac})$. Interestingly, the property use was more mixed than Toronto with $31 \%$ (9 projects) residential, $24 \%$ (7) retail, $14 \%$ (4) office, $14 \%$ (4) industrial, and $10 \%$ (3) other commercial. Four of the projects were still vacant parcels, with three being actively farmed and a fourth with a large condominium project under construction at the time of writing. Of the nine residential projects, five are condominiums, one is a rental apartment, one is a row of townhouses and two are semi-detached homes. In terms of units, $85 \%$ were in condominiums, $8 \%$ apartments, $6 \%$ row/townhouses, and $1 \%$ semi-detached. Geographically, the bulk of activity has taken place within the CIP area and in the older part of the city near the downtown core and along the central corridor (King Street) (see Figure 3).

The overall assessed value amounted to $\$ 147,642,271$ with an average of $\$ 4,921,409$ and a median of $\$ 1,997,875$. The majority of this value is in residential (58.5\%) and retail $(20.7 \%)$, with a relatively equal amount going to office and other commercial (9.4\% each) and in industrial and vacant/farm ( $1 \%$ each). Of the residential projects, $81.2 \%$ of value is in condominium apartments, $12.4 \%$ rental apartments, 5.4\% row/townhouses, and $1 \%$ detached dwellings. The vast majority of value lies in the new buildings constructed (94.8\%) versus properties that were rehabilitated (4.2\%) or vacant/farmed lots (1\%). Based on census 2011 averages it can be estimated that 491 persons reside in these residential units (82.1\% Condo, $7.8 \%$ row, $8.4 \%$ rental apartment, $1.6 \%$ semi).

\subsection{Kingston}

A total of 45 Records of Site Condition were filed in the City of Kingston from 2004 to 2011 (see figure 4). The land reclaimed amounted to 69.7 hectares (172.3 ac), with an average per RSC of $1.5 \mathrm{ha}(3.8 \mathrm{ac})$ and a median of $0.3 \mathrm{ha}(0.8 \mathrm{ac})$, with almost all RSCs covering the entire property $(82.2 \%)$. Most of the former brownfield sites were used for commercial (57.8\%) purposes, followed by industrial (17.8\%), residential (15.6\%), community $(6.7 \%)$ and institutional (2.2\%). As in Toronto, the most common intended use for these properties outlined in the RSCs was for residential use (75.6\%) followed to a much lesser extent by commercial (17.8\%) and institutional (6.7\%). In terms of site assessment and cleanup, $13.3 \%$ of RSCs only completed a Phase 1 ESA, whereas $82.2 \%$ filed a Phase 1 and 2 ESA and only $4.4 \%$ used risk-based procedures. All of the ten projects that included information about cleanup noted that they removed soil exceeding standards and deposited it in an authorized landfill, while $60 \%$ of RSCs noted the removal of some soil as part of the project.

A new on-line lookup tool allowed more up to date 2015 tax data to be gathered for Kingston. In all, thirtyeight properties with property assessment information addressed 102.3 hectares ( $254.3 \mathrm{ac})$, with an average per property of 0.6 ha $(1.4 \mathrm{ac})$ and a median of 2.7 ha $(6.7$ ac). In terms of the area reclaimed, the bulk of brownfield land was put back into reuse with within the CIP area, near the downtown core and in inner suburbs along the main arterial (Highway 2) and along the St. Lawrence River North, with very little in the outer suburbs (see Figure 4). Property use could be discerned for forty of the projects, with $23(58 \%)$ residential, $7(18 \%)$ vacant, $3(8 \%)$ retail, $3(5 \%)$ office, $2(5 \%)$ general commercial, $1(3 \%)$

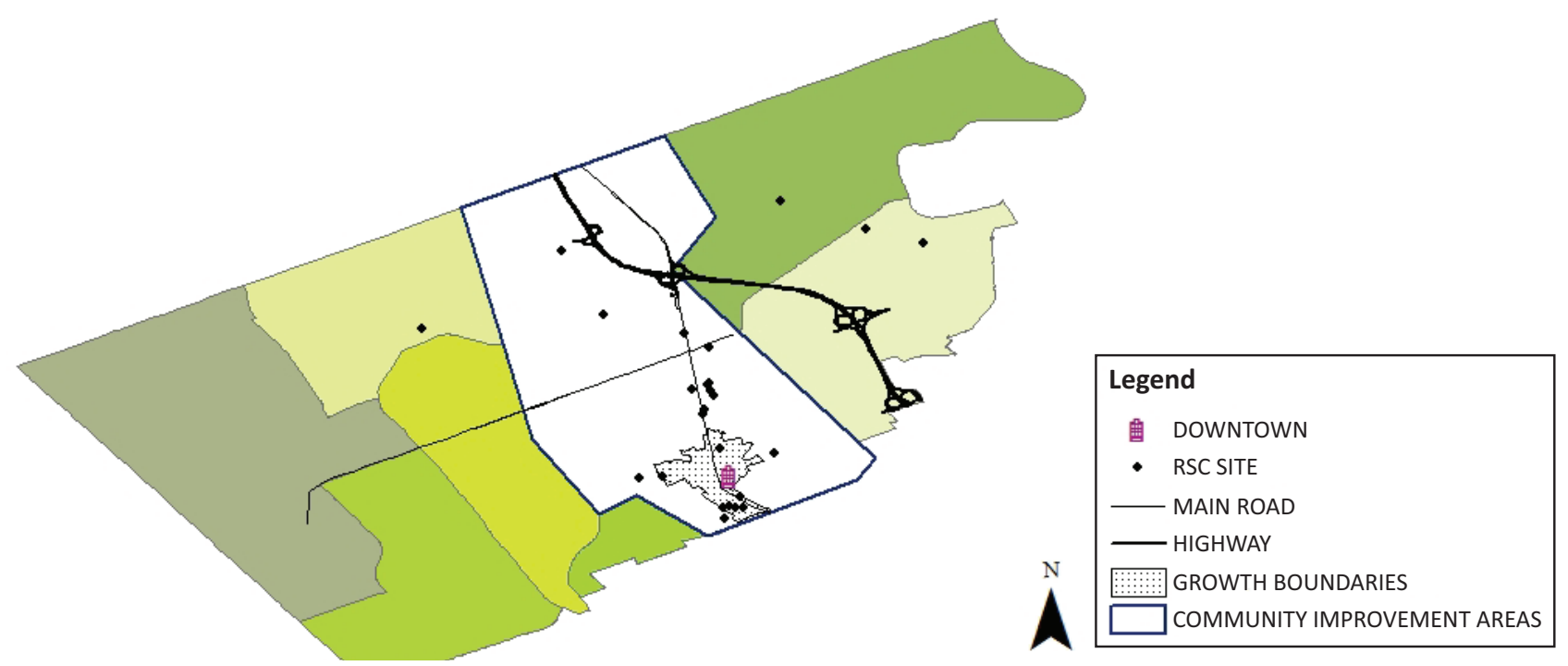

Figure 3. City of Waterloo (24 RSCs 2004-2011). 


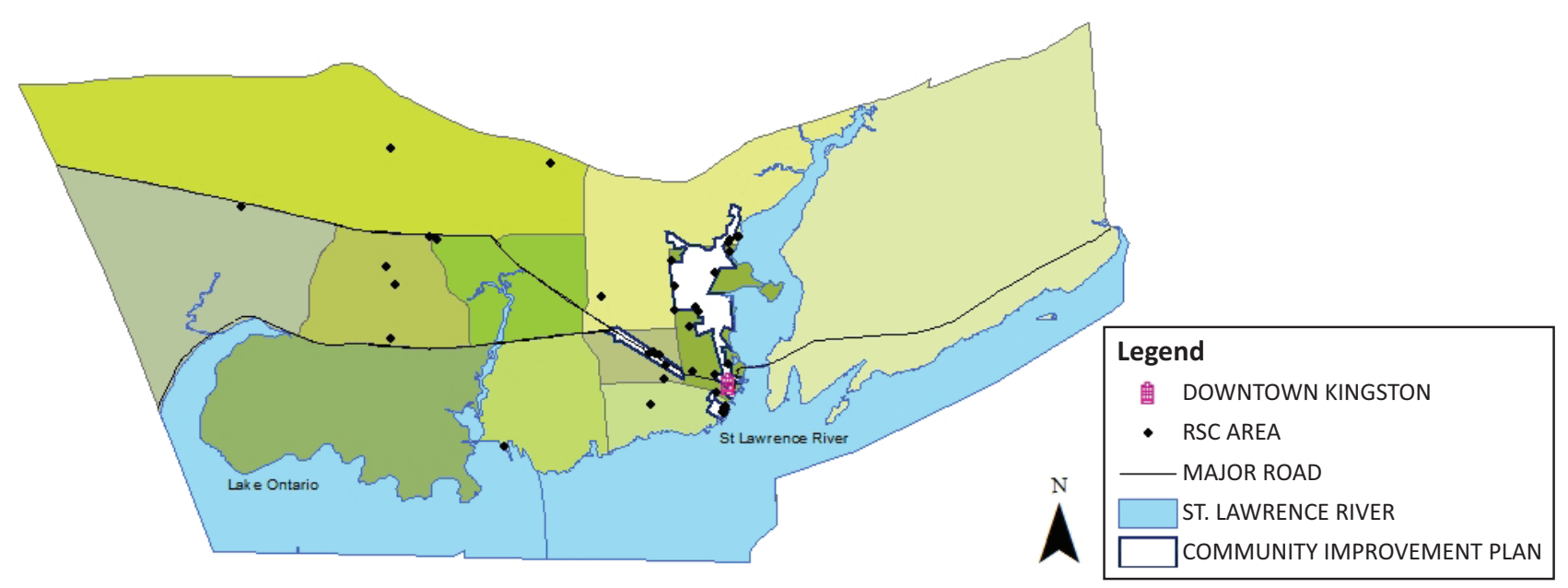

Figure 4. City of Kingston (45 RSCs 2004-2011).

industrial and 1 (3\%) institutional. Of the 25 residential projects, 8 are rental apartments, 8 are row houses (some rental and some own), 4 are condominium apartments, 4 single family projects, and one semi-detached. In terms of residential units, the greatest share of the 1,350 units are for rental apartments (65\% 884), followed by condominiums (17\% 236), row/townhouses (189 14\%), single family dwellings (3\% 40) and a semidetached unit. A review of the residential projects also reveals that $83 \%$ of the units were newly constructed, while the remainder involved renovation. In terms of units, virtually all of them were located in the downtown core and inner suburban neighborhoods. Given that Kingston had 5,532 dwelling starts from 2005-2011 (790 per year), one can infer that dwellings on brownfields represented under one sixth (17\%) of the total (Canadian Mortgage and Housing Corporation, 2015, p. 17).

Overall, the 2015 assessed value of thirty-nine brownfields with assessment data amounted to over $\$ 315,959,088$ dollars, with an average of $\$ 8,024,685$ and a median of $\$ 1,133,198$. The majority of this value is in residential (67.9\%) and retail $(22.5 \%)$ projects, followed by much smaller shares in commercial (5\%), office (3.5\%), vacant $(0.7 \%)$, industrial $(0.4 \%)$, and institutional $(0.1 \%)$. Of the residential projects, $40.8 \%$ (\$87.6 of $\$ 214.5$ million) is in condominium apartments, $28.8 \%$ in rental apartments, $20.2 \%$ in row/townhouses, $10.1 \%$ in single family dwellings and $0.1 \%$ in the detached dwelling. The vast majority of this value lies in the new buildings constructed (91\%), followed by upgraded apartments (7.4\%), rehabilitated buildings $(0.8 \%)$ and vacant lots $(0.5 \%)$; with the geography of this value follows the units. Using per person approximations for different dwelling types from the 2011 Census of Canada (CMA) 2,371 people reside on former brownfields.

\section{Discussion and Concluding Remarks}

Analysis of the RSCs and property assessment data reveal that brownfields redevelopment activity has been rather extensive in scale, character, and value during the time period examined, particularly in Toronto where it seems significantly higher than nearby US cities and more akin to residential development witnessed in England. Dense redevelopment also seems to be occurring in locations identified by the provincial growth plan, thus aligning with the prime sustainability objective of growing in-andup instead of out. Unlike in England however-where national targets were established, regional councils assess land availability to proactively identify brownfields suitable for housing and economic development, and local authorities generate and maintain public registers of brownfields available for housing-the approach taken for Toronto seems less defined and more reactive with the province setting population density targets for urban growth areas and the city seeming to allow market demand to protrude in those areas supported on a project-by-project basis through rezoning and density allowances. This, along with the Province's less intrusive voluntary cleanup approach, seems to be dealing with the 'development frictions' (costs, risks, and regulatory obstacles) associated with cleanup and redevelopment. The high degree of land conversion from commercial to residential use does expose the "blind side" of this reactive approach to smart growth planning (Leigh \& Hoetzel, 2012), which might be better served by the English approach that more directly includes economic development considerations in identifying and assessing land supply. As for higher order sustainability goals, Toronto introduced a Green Standard in 2010 requiring 'all' new planning applications to comply with so-called Tier 1 environmental performance measures akin to the green building requirements needed to achieve LEED (Leadership in Energy and Environmental Design) silver certification. While this forces developers to deal with environmental sustainability issues beyond sprawl, it does not incorporate economic or social sustainability spheres, which is also a challenge to private development in England as Dixon (2007) found. In terms of cleanup, pressure is also mounting in Ontario to reduce waste going 
to landfills and to treat contamination on-site, but most developers still prefer to dig-and-dump, as in the UK, to remove the risks and liabilities along with the contaminated soil.

The brownfields story is also positive for the smaller cities of Waterloo and Kingston, although its contribution to achieving sustainable growth objectives is much less robust. While building higher-density housing in core urban areas is part of their urban planning playbook, it is clear that there is less demand for such housing despite the fact that both municipalities have growth plans, brownfield support tools, and share the same voluntary cleanup regime. The more interventionist English approach identifying brownfields suitable for redevelopment-along with stricter controls on greenfield sprawl-might be better suited for smaller cities, where the market preference for low-density residential product and a plentiful supply of greenfields does not seem to be compelling the private sector to overcome development frictions and build most new supply on brownfields. In addition to having a limited impact on supporting sustainable growth, the ability to compel brownfield developers to engage more profoundly with sustainability becomes even more challenging and unless it is applied to all development equally, it will place them at a further disadvantage to greenfields.

In sum, the number of projects being undertaken and the high level of participation by the private market does point to brownfields reuse and redevelopment being a smart solution for sustainable cities. Though still more challenging than developing on clean greenfield sites, the data reveal that there is a growing comfort with Ontario's regulatory approach for assessing and remediating brownfields that is allowing developers to unlock land supply opportunities where the market demands it. It is also clear that strong growth pressure in large cities combined with provincial policy aimed at limiting sprawl and identifying locations for population density seems to be achieving the prime sustainability directive of growth management, while municipal requirements can also be used to force all development to engage with sustainability at a deeper level. While the English example of mandating development targets and identifying specific sites to achieve them might be perceived as too interventionist for Canada-especially given growing protest about current efforts in Toronto making prices unaffordablea more intentional, interventionist, and coordinated approach by all levels of government might actually facilitate development from both a quantity and quality perspective. By being more coordinated and proactive, governments in Ontario could go from suggesting broad targets and permitting what comes, to more strategically identifying development objectives and properties for growth that could be facilitated by public infrastructure investment along with allowances and incentives to spur private investment. This would, however, require governments and the public to be on the same page in terms of how we grow as a sustainable city and region, something that different political parties, levels of government, and low-density loving Canadians are still having trouble with. Regardless, aiming for the model of urban development recently set out in the UN General Assembly's New Urban Agenda (2016) that integrates all facets of sustainable development and seeks to prioritize renewal, regeneration, and retrofitting, compels governments and citizens to keep planning smart and to grow in-and-up or risk striking out.

\section{Acknowledgements}

This work was supported by the Social Sciences and Humanities Research Council of Canada under grant number 435-2014-1790. I would like to thank the MOECC and my research assistants T. Spiess, S. Mah, N. Kohek, S. Marchese, J. Kuehnhold, P. Bam, K. Galinac, and J. Ramakrishnan.

\section{Conflict of Interests}

The author declares no conflict of interests.

\section{References}

Adams, D. (2011). The 'wicked problem' of planning for housing development. Housing Studies, 26(6), 951960. doi:10.1080/02673037.2011.593128

Adams, D., De Sousa, C., \& Tiesdell, S. (2010). Brownfield development: A comparison of North American and British approaches. Urban Studies, 47(1), 75104. doi:10.1177/0042098009346868

Alberini, A., \& Segerson, K. (2002). Assessing voluntary programs to improve environmental quality. Environmental and Resource Economics, 22(1/2), 157-184. doi:10.1023/A:1015519116167

Blackman, A., Darley, S., Lyon, T., \& Wernstedt, K. (2010). What drives participation in state voluntary cleanup programs? Evidence from Oregon. Land Economics, 86(4), 785-799. doi:10.3368/le.86.4.785

Canadian Mortgage and Housing Corporation. (2015). Housing now: Kingston Census Metropolitan Area. Ottawa: Queen's Printer for Canada.

City of Kingston. (2004). Final report: City of Kingston urban growth strategy. Kingston: City of Kingston.

City of Toronto. (2015). Housing occupancy trends 19962011. Toronto: City Planning Division, City of Toronto.

City of Toronto. (2016). Profile Toronto: How does the city grow? Toronto: City Planning Division, City of Toronto.

De Sousa, C. (2002a). Measuring the public costs and benefits of brownfield versus greenfield development in the Greater Toronto Area. Environment and Planning B: Planning and Design, 29(2), 251-280. doi:10.1068/b1283

De Sousa, C. (2002b). Brownfield redevelopment in Toronto: An examination of past trends and future prospects. Land Use Policy, 19(4), 297-309. doi:10.1016/S0264-8377(02)00024-8 
De Sousa, C. (2008). Brownfields redevelopment and the quest for sustainability. Oxford: Elsevier.

De Sousa, C. (2015). Overcoming barriers and facilitating brownfields redevelopment in the GTHA: A review of results from interviews with private sector stakeholders. Toronto: Center for Urban Research and Land Development, Ryerson University.

Deason, J., Sherk, G. W., \& Carroll, G. A. (2001). Public policies and private decisions affecting the redevelopment of brownfields: An analysis of critical factors, relative weights and areal differentials. Washington, DC: Environmental and Energy Management Program, George Washington University.

Dixon, T. (2007). The property development industry and sustainable urban brownfield regeneration in England: An analysis of case studies in Thames Gateway and Greater Manchester. Urban Studies, 44(12), 2379-2400. doi:10.1080/00420980701540887

Fishlock, R. (2011). Brownfields reform in Ontario. Toronto, ON: Blake, Cassels \& Graydon. (Reprinted from Key developments in environmental Law, 2010, Aurora, ON: Canada Law Book). Retrieved from http://www.blakesfiles.com/Reports/2011_Blakes_ Brownfields_Reform_in_Ontario_EN.pdf

Greenstein, R., \& Sungu-Eryilmaz, Y. (2004). Recycling the city: The use and reuse of urban land. Cambridge, MA: Lincoln Institute of Land Policy.

Guignet, D., \& Alberini, A. (2010). Voluntary cleanup programs and redevelopment potential: Lessons from Baltimore, Maryland. Cityscape, 12(3), 7-36.

Hayek, M., Arku, G., \& Gilliland, J. (2010). Assessing London Ontario's brownfield redevelopment effort to promote urban intensification. Local Environment, 15(4), 389-402. doi:10.1080/13549831003677712

Hollander, J., Kirkwood, N., \& Gold, J. (2010). Principles of brownfield regeneration: Cleanup, design, and reuse of derelict land. Washington, DC: Island Press.

Kirkwood, N. (2001). Manufactured sites: Rethinking the post-industrial landscape. London: Spon Press.

Leigh, N. G., \& Hoelzel, N. Z. (2012). Smart growth's blind side: Sustainable cities need productive urban industrial land. Journal of the American Planning Association, 78(1), 87-103. doi:10.1080/ 01944363.2011.645274

Ministry of Municipal Affairs and Housing. (2005a). Places to grow act. Toronto, ON: Queen's Printer for Ontario.

Ministry of Municipal Affairs and Housing. (2005b). Greenbelt plan. Toronto, ON: Queen's Printer for Ontario.

Ministry of Municipal Affairs and Housing. (2006a). Bill 51, planning and conservation land statute law amendment act. Toronto, ON: Queen's Printer for Ontario.

Ministry of Municipal Affairs and Housing. (2006b). Planning act. Toronto, ON: Queen's Printer for Ontario.

Ministry of Municipal Affairs and Housing. (2007). A practical guide to brownfield redevelopment in Ontario. Toronto: Queen's Printer for Ontario.
Ministry of Municipal Affairs and Housing. (2008). Brownfields financial tax incentive program (BFTIP). Toronto, ON: Queen's Printer for Ontario.

Ministry of Municipal Affairs and Housing. (2010). Municipal financial incentives for brownfield redevelopment: Trends among Ontario municipalities. Toronto, ON: Queen's Printer for Ontario.

Ministry of the Environment and Climate Change. (1971). Environmental protection act. 1990. Toronto, ON: Queen's Printer for Ontario.

Ministry of the Environment and Climate Change. (1989). Guidelines for the decommissioning and cleanup of sites in Ontario. Toronto, ON: Waste Management Branch, Ontario Ministry of the Environment.

Ministry of the Environment and Climate Change. (1993). Interim guideline for the assessment and management of petroleum contaminated sites in Ontario. Toronto, ON: Hazardous Contaminants Branch, Ontario Ministry of the Environment.

Ministry of the Environment and Climate Change (2001). Brownfields statute law amendment act, Government of Ontario (c-17, Bill 56). Toronto, ON: Queen's Printer for Ontario.

Ministry of the Environment and Climate Change. (2004a). Regulation 153/04 records of site condition-Part XV.1 of the Act. Toronto, ON: Queen's Printer for Ontario.

Ministry of the Environment and Climate Change. (2004b). Records of site condition and transition notices. Environmental Site Registry. Retrieved from https://www.Ircsde.Irc.gov.on.ca/besrWebPub lic/generalSearch

Ministry of the Environment and Climate Change. (2015). Brownfields redevelopment. Toronto, ON: Brownfields, Environmental Clean-up \& Financial Assurance Services, Environmental Approvals Access and Service Integration Branch.

Nagengast, A., Hendrickson, C., \& Lange, D. (2011). Commuting from US brownfield and greenfield residential development neighborhoods. Journal of Urban Planning and Development, 137(3), 298-304. doi:10.1061/(ASCE)UP.1943-5444.0000072

Ontario Ministry of Infrastructure. (2013). Growth plan for the Greater Golden Horseshoe, 2006, office consolidation, June 2013. Toronto: Queen's Printer for Ontario.

Region of Waterloo. (2009). Implementation guideline for the review of development applications on or adjacent to known and potentially contaminated sites (Report No. P-09-046). Kitchener, ON: Regional Municipality of Waterloo.

Sarni, W. (2009). Greening brownfields: Remediation through sustainable development. New York: McGraw-Hill.

Sinnett, D., Carmichael, L., Williams, K., \& Miner, P. (2014). From wasted space to living spaces. London: Campaign to Protect Rural England.

United Nations General Assembly. (2016). New urban 
agenda: Quito declaration on sustainable cities and human settlements for all (Resolution adopted by the General Assembly on 23 December 2016). New York: United Nations.

United States Conference of Mayors. (2010). Recycling America's land: A national report on brownfields redevelopment (1993-2010). Washington, DC: United States Conference of Mayors.

United States Environmental Protection Agency. (1998). Characteristics of sustainable brownfields projects (Report EPA-R-98-001). Washington, DC: US EPA, Office of Solid Waste and Emergency Response.

United States Environmental Protection Agency. (1999). A sustainable brownfields model framework (Report EPA500-R-99-001). Washington, DC: US EPA, Office of
Solid Waste and Emergency Response.

Wedding, G. C., \& Crawford-Brown, D. (2007). Measuring site-level success in brownfield redevelopments: A focus on sustainability and green building. Journal of Environmental Management, 85(2), 483-495. doi:10.1016/j.jenvman.2006.10.018

Wernstedt, K., Blackman, A., Lyon, T., \& Novak, K. (2013). Revitalizing underperforming and contaminated land through voluntary action: Perspectives from US voluntary cleanup programs. Land Use Policy, 31, 545556. doi: 10.1016/j.landusepol.2012.08.018

White, R. (2007). The growth plan for the Greater Golden Horseshoe in historical perspective. Toronto: The Neptis Foundation.

\section{About the Author}

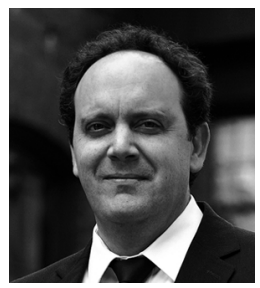

Christopher De Sousa is Professor and Director of the School of Urban and Regional Planning at Ryerson University. His research activities focus on various aspects of brownfields redevelopment in Canada and the US. He is currently on the Board of Directors of the Canadian Brownfields Network, a Steering Committee Member on the US ATSDR Brownfields/Land Reuse Health Initiative, and on the Executive Committees for Ryerson's City Building Institute and Centre for Urban Research and Land Development. 